\title{
Gene expression of muscarinic, tachykinin, and purinergic receptors in porcine bladder: comparison with cultured
}

\section{cells}

\author{
Forough Bahadory ${ }^{1}$, Kate H. Moore ${ }^{2}$, Lu Liu ${ }^{1}$ and Elizabeth Burcher ${ }^{1}$ * \\ 1 Department of Pharmacology, School of Medical Sciences, University of New South Wales, Sydney, NSW, Australia \\ 2 Detrusor Muscle Laboratory, St. George Hospital, University of New South Wales, Kogarah, NSW, Australia
}

Edited by:

Daniel Moura, University of Porto, Portugal

Reviewed by:

Medardo Hernández, Universidad

Complutense de Madrid, Spain

Paulo Correia-de-Sá, Instituto de

Ciências Biomédicas Abel Salazar da

Universidade do Porto, Portugal

*Correspondence:

Elizabeth Burcher, Department of Pharmacology, School of Medical Sciences, University of New South Wales, Sydney, NSW 2052, Australia e-mail:e.burcher@unsw.edu.au
Urothelial cells, myofibroblasts, and smooth muscle cells are important cell types contributing to bladder function. Multiple receptors including muscarinic $\left(M_{3} / M_{5}\right)$, tachykinin $\left(\mathrm{NK}_{1} / \mathrm{NK}_{2}\right)$, and purinergic $\left(\mathrm{P}_{2} \mathrm{X}_{1} / \mathrm{P}_{2} \mathrm{Y}_{6}\right)$ receptors are involved in bladder motor and sensory actions. Using female pig bladder, our aim was to differentiate between various cell types in bladder by genetic markers. We compared the molecular expression pattern between the fresh tissue layers and their cultured cell counterparts. We also examined responses to agonists for these receptors in cultured cells. Urothelial, suburothelial (myofibroblasts), and smooth muscle cells isolated from pig bladder were cultured (10-14 days) and identified by marker antibodies. Gene (mRNA) expression level was demonstrated by real-time PCR. The receptor expression pattern was very similar between suburothelium and detrusor, and higher than urothelium. The gene expression of all receptors decreased in culture compared with the fresh tissue, although the reduction in cultured urothelial cells appeared less significant compared to suburothelial and detrusor cells. Cultured myofibroblasts and detrusor cells did not contract in response to the agonists acetylcholine, neurokinin $A$, and $\beta, \gamma$-MeATP, up to concentrations of 0.1 and $1 \mathrm{mM}$. The significant reduction of $\mathrm{M}_{3}, \mathrm{NK}_{2}$, and $\mathrm{P} 2 \mathrm{X}_{1}$ receptors under culture conditions may be associated with the unresponsiveness of cultured suburothelial and detrusor cells to their respective agonists. These results suggest that under culture conditions, bladder cells lose the receptors that are involved in contraction, as this function is no longer required. The study provides further evidence that cultured cells do not necessarily mimic the actions exerted by intact tissues.

Keywords: smooth muscle, urothelium, suburothelium, myofibroblasts, muscarinic receptors, tachykinin receptors, purinergic receptors, cell culture

\section{INTRODUCTION}

Interactions between various neurochemicals and receptors are essential for normal sensory and motor function in the urinary bladder (Birder, 2013; Burnstock, 2013). The main neurotransmitters involved in detrusor muscle contraction and relaxation are acetylcholine (ACh) and noradrenaline (NA), respectively, (Ochodnicky et al., 2013). Other mediators such as adenosine triphosphate (ATP), nitric oxide (NO), and tachykinins are also involved in bladder function, and are of importance in stimulating afferent signaling pathways (Ishizuka et al., 1995; Otomo et al., 1999; Whitbeck et al., 2007).

In recent years it has become apparent that the bladder lining (urothelium and lamina propria, collectively known as the mucosa) may play a significant role in the initiation and propagation of afferent signals during bladder filling (Fry et al., 2007). The mucosa contains various cell types, of major interest being spindle shaped cells known as myofibroblasts, mainly located in the suburothelium (Cheng et al., 2011). These cells are connected by gap junctions (connexin 43), and localized in a close proximity to C fiber nerves (Wiseman et al., 2003) and other cell types in the bladder wall (McCloskey, 2010). The function of myofibroblasts is not fully understood. However, studies have shown that these cells can elicit spontaneous electrical currents, and respond to exogenous agents such as ATP via $\mathrm{P}_{2} \mathrm{Y}_{6}$ receptors (Wu et al., 2004). Furthermore, our group has shown the potent contractility of bladder suburothelium in response to the tachykinin and muscarinic receptor agonists; it was suggested that myofibroblasts might be the cell type responsible for suburothelial contraction (Sadananda et al., 2008, 2012).

Porcine bladder is a well recognized model for the human bladder (Templeman et al., 2003; Kumar et al., 2004; Sadananda et al., 2008). Previously, our group illustrated that three distinct cell types: urothelial, myofibroblast, and detrusor muscle, can be cultured from porcine bladder (Cheng et al., 2011). The cells were distinguished on the basis of morphological, immunological, and pharmacological characterization and were able to release ATP in response to stretch (Cheng et al., 2011), but the differences in gene expression between various cell types in bladder have not been studied.

Our primary aim was to examine the gene expression and distribution pattern of the principal receptors mediating contraction of the urinary bladder: muscarinic $\mathrm{M}_{3}$, tachykinin $\mathrm{NK}_{2}$, and 
purinergic $\mathrm{P}_{2} \mathrm{X}_{1}$ receptors. We also studied expression of $\mathrm{M}_{5}$ and $\mathrm{P}_{2} \mathrm{Y}_{6}$ receptors. We compared the expression in tissue from three bladder regions: urothelium, suburothelium (the dissected mucosa minus urothelium), and detrusor, with their cultured cell counterparts. We hypothesized that the cultured cells would show similarities to the fresh tissue with respect to gene expression, and that each cultured cell type should be characterized by a different set of genetic markers. This study also examined any phenotypic alteration of the cells in culture, as reported for smooth muscle cells (Nair et al., 2011; Huber and Badylak, 2012), and determined the reliability of primary cultured cells in investigating the function of isolated bladder cell types. We also examined the functional properties of the cultured cells, using agonists for muscarinic $\mathrm{M}_{3}$, tachykinin $\mathrm{NK}_{2}$, and purinergic $\mathrm{P} 2 \mathrm{X}_{1}$ receptors, in suburothelium and detrusor. To our knowledge this is the first report of gene expression for those receptors in the porcine bladder.

\section{METHODS AND MATERIALS TISSUE PREPARATION AND CELL CULTURE}

Female pigs (6-9 months, $\sim 55 \mathrm{~kg}$ ), were sacrificed at a local abattoir. Bladders were collected and transported on ice to the laboratory. Any damaged or inflamed bladders were discarded. Fat tissue was removed and bladders were rinsed with KrebsHenseleit solution.

For cell culture and molecular studies, the urothelial tissue (UT) was scraped off using a scalpel blade. To remove any residual urothelium, trypsin $(0.25 \%$ with EDTA $)$ was then applied to the luminal surface for $5 \mathrm{~min}$ at $37^{\circ} \mathrm{C}$, neutralized with RPMI culture medium and rinsed with Krebs-Henseleit solution. The bladder (minus urothelium) was then dissected into two layers, the mucosa and the detrusor (DT). The mucosa was further dissected under a microscope to remove the residual muscle bundles and blood vessels, as described (Sadananda et al., 2008), leaving a thin layer of suburothelium (ST) used in this study. We did not attempt to separate myofibroblasts from fibroblasts.

One half of these fresh dissected tissues was snap frozen and stored at $-80^{\circ} \mathrm{C}$ overnight for molecular studies. The remainder was minced, and treated with $0.25 \%$ trypsin-EDTA with $0.15 \%$ collagenase type II for $30 \mathrm{~min}$ at $37^{\circ} \mathrm{C}$, followed by neutralization with RPMI culture medium. The cells cultured into three populations: urothelial cells (UC), suburothelial cells (SC) which included myofibroblasts, and detrusor muscle cells (DC), as described (Cheng et al., 2011). Cells were harvested after 10-14 days in primary culture.

\section{FLUORESCENT IMMUNOHISTOCHEMISTRY AND IMMUNOCYTOCHEMISTRY}

Additional segments of porcine bladder dome were fixed in Zamboni's solution overnight at $4^{\circ} \mathrm{C}$. The segments were washed in dimethyl sulfoxide (DMSO, $3 \times 10 \mathrm{~min}$ ), rinsed in phosphate buffered saline (PBS, $0.1 \mathrm{M}, \mathrm{pH}=7.4$ ), and then immersed in $30 \%$ sucrose in PBS overnight at $4^{\circ} \mathrm{C}$. Paraffin sections were processed (dewaxation and rehydration), and preincubated with hydrogen peroxide $(3 \%)$ for $5-8 \mathrm{~min}$, followed by incubation overnight at room temperature with primary marker antibodies: AE1/AE3 (M3515), vimentin (M0725), or $\alpha$-smooth muscle actin (M0851) ( $\alpha$-SMA, 1:500 dilution with 2\% goat serum). Immunostaining with c-kit (SC 13508) was also attempted. Thereafter, slides were rinsed $(3 \times 5 \mathrm{~min})$ with $\mathrm{PBS}$ and incubated with the secondary antibody (FITC-conjugated anti-mouse IgG antibody, 1:100 in $2 \%$ goat serum) at room temperature for $1 \mathrm{~h}$. The sections were washed with PBS and coverslipped with mounting medium (ProLong ${ }^{\circledR}$ Gold Antifade Reagent with DAPI, Life technologies). In each run, negative controls (no primary antibody), and positive controls (human colon) were also included. The fields were observed using a fluorescence microscope (EVOS fl: filter GFP, $40 \times$ magnification).

Cultured cells were also immunostained to confirm their identity. Ethanol (100\%) was added to culture wells for $15 \mathrm{~min}$ at room temperature to fix the cells, which were then permeabilized with $0.1 \%$ Triton X-100 in PBS for $10 \mathrm{~min}$. The primary and secondary antibodies were applied as above.

\section{MASSON'S TRICHROME BLUE STAIN}

Sections adjacent to those used fluorescent immunohistochemistry were stained with Masson's trichrome to delineate connective tissue from smooth muscle and from urothelial cells. In brief, sections were re-hydrated with ethanol and then distilled water, stained in hematoxylin for $10 \mathrm{~min}$, and rinsed in warm tap water for $10 \mathrm{~min}$. They were covered by Biebrich scarlet-acid fuchsin solution for $15 \mathrm{~min}$ followed by washing in distilled water. The sections were incubated in phosphomolybdic-phosphotungstic acid solution for $15 \mathrm{~min}$ or until the collagen was not red, then covered by aniline blue solution for 5-10 $\mathrm{min}$. They were washed in distilled water briefly, and were differentiated using $1 \%$ acetic acid solution for 2-5 min. After rinsing in water, the sections were dehydrated, cleared in xylene and mounted.

\section{RNA EXTRACTION AND RT-PCR}

RNA was extracted from thawed bladder tissues $(n=10-14)$ and $80 \%$ confluent cultured cells by the TRIzol method (Invitrogen). Total RNA $(2 \mu \mathrm{g})$ was subjected to single strand cDNA synthesis using a SuperScript ${ }^{\mathrm{TM}}$ III First-Strand Synthesis System. The genes under investigation encoded for the muscarinic $\mathrm{M}_{3}$ and $\mathrm{M}_{5}$ receptors, the tachykinin receptors $\left(\mathrm{NK}_{1}\right.$ and $\left.\mathrm{NK}_{2}\right)$, and the purinergic $\mathrm{P}_{2} \mathrm{X}_{1}$ and $\mathrm{P}_{2} \mathrm{Y}_{6}$ receptors. The gene sequences of interest were derived from the pig genome (National Centre for Biotechnology Information, NCBI), and primers were designed using Primer 3.0 software (Table 1). The gene sequence for $\mathrm{NK}_{1}$ receptor in porcine genome is not published in NCBI, therefore, the primers for the $\mathrm{NK}_{1}$ receptor were derived from sequences conserved across a broad range of mammalian species (human, cow, dog, and mouse). Gene expression was determined by quantitative real-time polymerase chain reaction (qRT-PCR) using the KAPA $^{\text {TM }}$ SYBR $^{\circledR}$ FAST kit as described (Liu et al., 2011; Dai et al., 2012). GAPDH was used as the housekeeping gene (HKG), and mRNA from an intact pig bladder tissue was used as the internal calibrator.

Data were expressed as mean \pm s.e.m. The mRNA level for each gene was expressed as fold change relative to GAPDH and the calibrator using the formula:

Fold change $=2^{-\Delta \Delta \mathrm{Ct}}$, where $\Delta \Delta \quad \mathrm{C}_{t}=\left[\mathrm{C}_{t}\right.$ (target) $\left.\quad-\mathrm{C}_{t}(\mathrm{HKG})\right]$ sample $\left[\mathrm{C}_{t}\right.$ (target) - $\left.\mathrm{C}_{t}(\mathrm{HKG})\right]$ calibrator (Pfaffl, 2001). For each gene, One-Way ANOVA followed by Bonferroni's multiple 
Table 1 | Oligonucleotide primers used in the real-time PCR studies.

\begin{tabular}{|c|c|c|c|}
\hline Gene & Protein & $\begin{array}{l}\text { Primer sequence }\left(5^{\prime}-3^{\prime}\right) \text {, } \\
\text { forward/reverse }\end{array}$ & $\begin{array}{l}\text { Product } \\
\text { size } \\
\text { (bp) }\end{array}$ \\
\hline$p \mathrm{Chrm}_{3}$ & $M_{3}$ & $\begin{array}{l}\text { GCCATCTACTCCATCGTGCT/ } \\
\text { CTCTTCTGGGCTTGCAGTTT }\end{array}$ & 152 \\
\hline$p C_{h r m}$ & $\mathrm{M}_{5}$ & $\begin{array}{l}\text { GTCTGAGCCCACCATCACTT } \\
\text { AAGAGGCTTGGTTCCTTTCC }\end{array}$ & 248 \\
\hline pTACR ${ }_{1}^{*}$ & $\mathrm{NK}_{1}$ & $\begin{array}{l}\text { TACTCCATGACGGCTGTGG/ } \\
\text { ATCTTGTTGGGATGCTCTGG }\end{array}$ & 212 \\
\hline pTACR 2 & $\mathrm{NK}_{2}$ & $\begin{array}{l}\text { CCTGTGATGTGGTGACTGATG/ } \\
\text { GCCAGGTTGACGATGAAGTAG }\end{array}$ & 204 \\
\hline$p P 2 R X_{1}$ & $\mathrm{P} 2 \mathrm{X}_{1}$ & $\begin{array}{l}\text { TCATCAAGAACAGCATCAGCTT/ } \\
\text { CAGTCCAGGTCACAGTTCCA }\end{array}$ & 232 \\
\hline$p P 2 R Y_{6}$ & $\mathrm{P}^{2} \mathrm{Y}_{6}$ & $\begin{array}{l}\text { CCACCCACTACATGCCCTAT } \\
\text { GTGATGTGGAAAGGCAGGAA }\end{array}$ & 217 \\
\hline pGapdh & GAPDH & $\begin{array}{l}\text { ACCCAGAAGACTGTGGATGG/ } \\
\text { CCCCAGCATCAAAGGTAGAA }\end{array}$ & 346 \\
\hline
\end{tabular}

Primer sequences are based on the pig genome except for pTACR ${ }_{1}\left({ }^{*}\right)$ which is based on the sequences in other mammalian species.

comparison tests was used to compare the mean values between tissues and cells, as well as between different tissues. For all studies, the $n$-value was taken as the number of pigs.

\section{FUNCTIONAL STUDIES WITH CULTURED CELLS}

Cultured suburothelial and detrusor muscle cells (10-14 days) were exposed to PBS (control), ACh $(10 \mu \mathrm{M}-1 \mathrm{mM})$, carbachol $(1 \mu \mathrm{M}-10 \mathrm{mM})$, NKA $(1-100 \mu \mathrm{M}), \beta, \gamma$-MeATP $(1 \mu \mathrm{M}-1 \mathrm{mM})$, as well as $\mathrm{KCl}(80$ and $160 \mathrm{mM})$, and photographed every $5 \mathrm{~s}$ up to $5 \mathrm{~min}$. The changes in the length and width of the cells were measured using Image (National Institutes of Health, USA).

\section{MATERIALS}

Cell culture products, TRIzol RNA purification reagent and SuperScript ${ }^{\mathrm{TM}}$ III First-Strand cDNA Synthesis System were obtained from Invitrogen (Mt Waverley, Australia). DNase enzymes were from Promega (Madison, USA). Primers, RNALater and the $\mathrm{KAPA}^{\mathrm{TM}} \mathrm{SYBR}^{\circledR}$ FAST qPCR reagents were from GeneWorks (Adelaide, Australia). Primary antibodies were from DakoCytomation (Campbellfield, Australia). The c-kit antibody was obtained from Santa Cruz Biotechnology, Dallas, Texas, USA. FITC-conjugated anti-mouse IgG was from Abcam (Waterloo, Australia). ACh, carbachol, NKA, and $\beta, \gamma$-MeATP were purchased from Sigma-Aldrich (Sydney, Australia). NKA was initially dissolved in $0.01 \mathrm{M}$ acetic acid with $1 \% \beta$-mercaptoethanol, and other agonists were dissolved in Krebs-Henseleit solution.

\section{RESULTS}

\section{FLUORESCENT IMMUNOHISTOCHEMISTRY AND IMMUNOCYTOCHEMISTRY}

Adjacent sections of whole porcine bladder were stained histologically with Masson's (Figure 1A) to reveal histological features, and immunostained with marker antibodies (Figures 1B-D). The urothelium was stained by the cytokeratin marker AE1/AE3
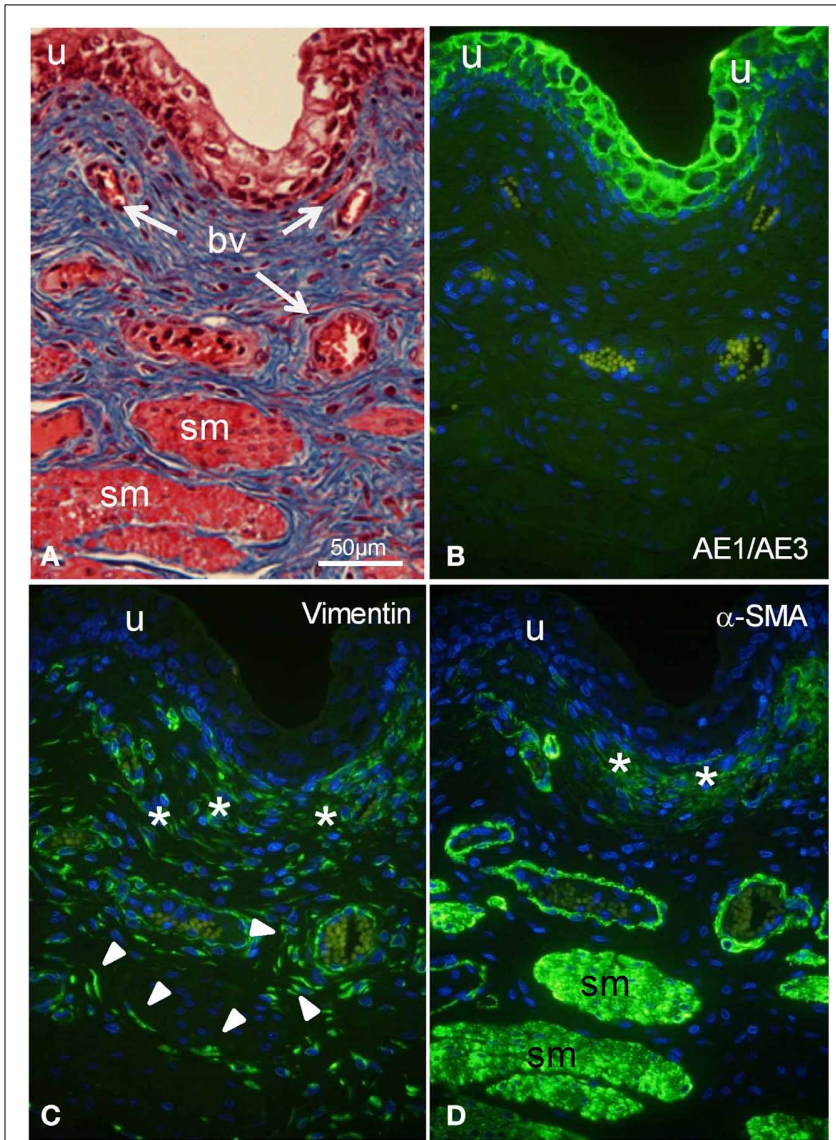

FIGURE 1 | (A) Histological staining (A) and fluorescent immunostaining (B-D) of intact segments of porcine bladder. (A) Masson's staining showing urothelium (u), smooth muscle bundles (sm), and blood vessels (bv). (B) Immunocytochemical characterization with AE1/AE3 (cytokeratin marker) shows staining of urothelium only. (C) Immunostaining with vimentin shows labeling of large spindle-shaped cells (arrowheads) and a cell layer (*) under the urothelium. (D) Immunostaining with $\alpha$-SMA (smooth muscle marker) shows labeling of smooth muscle bundles, the outer perimeter of blood vessels as well as part of a cell layer (*, suburothelium) under the urothelium. All cells were double stained with DAPI (cell nuclei, blue). All panels are shown at the same magnification. Bar $=50 \mu \mathrm{m}$.

(Figure 1B) but not by vimentin (Figure 1C) or by $\alpha$-SMA (Figure 1D). A cell layer $40-50 \mu \mathrm{m}$ thick under the urothelium was stained moderately by both vimentin and $\alpha$-SMA. Blood vessels in the lamina propria were stained strongly by $\alpha$-SMA and weakly by vimentin. Detrusor muscle bundles were stained strongly by $\alpha$-SMA and not at all by vimentin. However, large spindle shaped cells throughout the lamina propria were stained only by vimentin.

Cultured urothelial cells were stained by AE1/AE3 (Figure 2A), but showed no immunoreactivity for vimentin or $\alpha$-SMA (Figures 2B,C). The morphology of cultured suburothelial cells (myofibroblasts) and detrusor muscle cells was very similar, and neither showed any immunoreactivity to AE1/AE3 (Figures 2D,G). Suburothelial cells displayed strong immunoreactivity to vimentin (Figure 2E), but weak immunoreactivity to $\alpha$-SMA (Figure 2F). Cultured detrusor muscle cells, on the other 
hand, showed strong staining for both vimentin and $\alpha$-SMA (Figures 2H,I). Sections in which the primary antibody was omitted (negative controls) showed no autofluorescence except for erythrocytes (not shown). Staining with the c-kit antibody was unsuccessful in the pig bladder.

\section{GENE EXPRESSION}

In fresh frozen tissues, all transcripts, except $\mathrm{M}_{5}$, were highly expressed in detrusor and suburothelium, but often poorly expressed in the urothelium (Table 2 and Figure 3). Expression

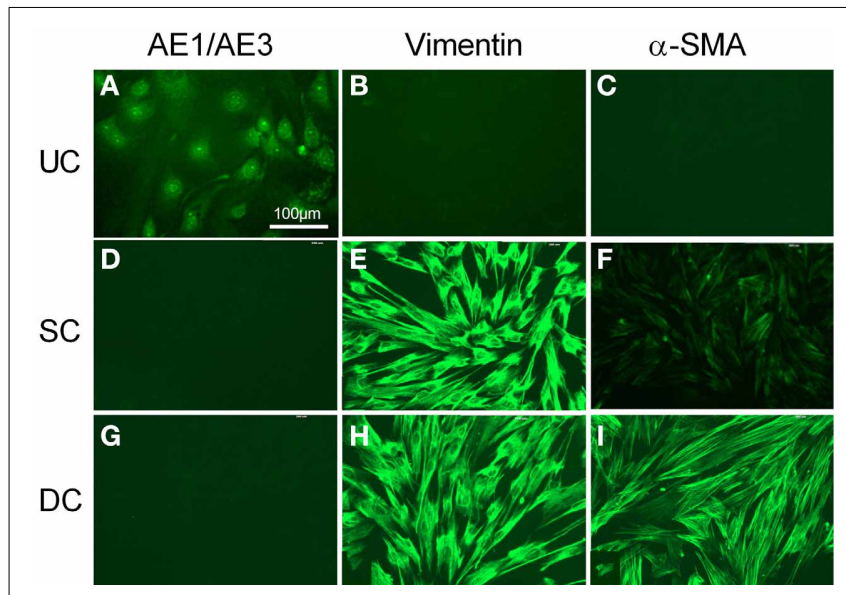

FIGURE 2 | Fluorescent immunocytochemical characterization of cultured urothelial cells (A-C), suburothelial cells (D-F), and detrusor smooth muscle cells $(\mathbf{G}-\mathbf{I})$. Cells $(\mathbf{A}, \mathbf{D}, \mathbf{G})$ were immunostained by AE1/AE3 (cytokeratin marker), (B,E,H) by vimentin, and $\mathbf{( C , F , I ) ~ b y ~} \alpha-S M A$ (smooth muscle marker). Cells were double stained with DAPI (cell nuclei, blue). All panels are shown at the same magnification. Bar $=100 \mu \mathrm{m}$. of the muscarinic $\mathrm{M}_{3}$ receptor was similarly high in both suburothelium and detrusor, and extremely low in urothelium. Muscarinic $\mathrm{M}_{5}$ expression was fairly similar in suburothelium and urothelium, but lower in detrusor. The expression order for the $\mathrm{NK}_{2}$ receptor was suburothelium $>$ detrusor $>$ urothelium, whereas the purinergic $\mathrm{P}_{2} \mathrm{X}_{1}$ receptor was expressed in detrusor $>$ suburothelium, but not in urothelium. $\mathrm{P}_{2} \mathrm{Y}_{6}$ was highly expressed in suburothelial tissues $>$ urothelium $=$ detrusor.

In general, expression of the receptor transcripts decreased in cell culture compared with that in the corresponding fresh tissues (Figure 3). For $\mathrm{M}_{3}, \mathrm{NK}_{2}$, and $\mathrm{P}_{2} \mathrm{X}_{1}$, in particular, this reduction was highly significant with respect to cultured suburothelium and detrusor. In contrast, the reduction in cultured urothelial cells was not significant for any transcript. Notably, no expression of the tachykinin $\mathrm{NK}_{1}$ receptor was observed in any tissues or cultured cells of the pig bladder.

Table 2 | Gene expression level for receptor transcripts in urothelium, suburothelial, and detrusor tissues.

\begin{tabular}{llllll}
\hline Tissue type & \multicolumn{5}{c}{ Receptors } \\
\cline { 2 - 6 } & $\mathbf{M}_{\mathbf{3}}$ & $\mathbf{M}_{\mathbf{5}}$ & $\mathbf{N} \mathbf{N}_{\mathbf{2}}$ & $\mathbf{P 2 \mathbf { X } _ { \mathbf { 1 } }}$ & $\mathbf{P 2 Y}_{\mathbf{6}}$ \\
\hline Urothelium & 0.05 & 4.22 & 0.38 & $\sim 0.00$ & 1.46 \\
Suburothelium & $1.29^{*}$ & 6.69 & $16.1^{* * *}$ & $1.45^{* * *}$ & $11.5^{* *}$ \\
Detrusor & $1.89 * * *$ & $1.79^{\dagger \dagger}$ & $7.46^{*}$ & $2.69 * 9^{* *}{ }^{\dagger+\dagger}$ & $1.36^{\dagger \dagger}$ \\
\hline
\end{tabular}

Data expressed as fold change compared to the calibrator and GAPDH.

${ }^{*} P<0.05 ;{ }^{* *} P<0.01 ;{ }^{* * *} P<0.001 ;{ }^{* * *} P<0.0001$, compared with urothelium.

${ }^{t} P<0.05 ;{ }^{H} P<0.01 ;{ }^{H t} P<0.001$, compared with suburothelium (One-Way ANOVA, followed by Bonferroni's multiple comparisons test).
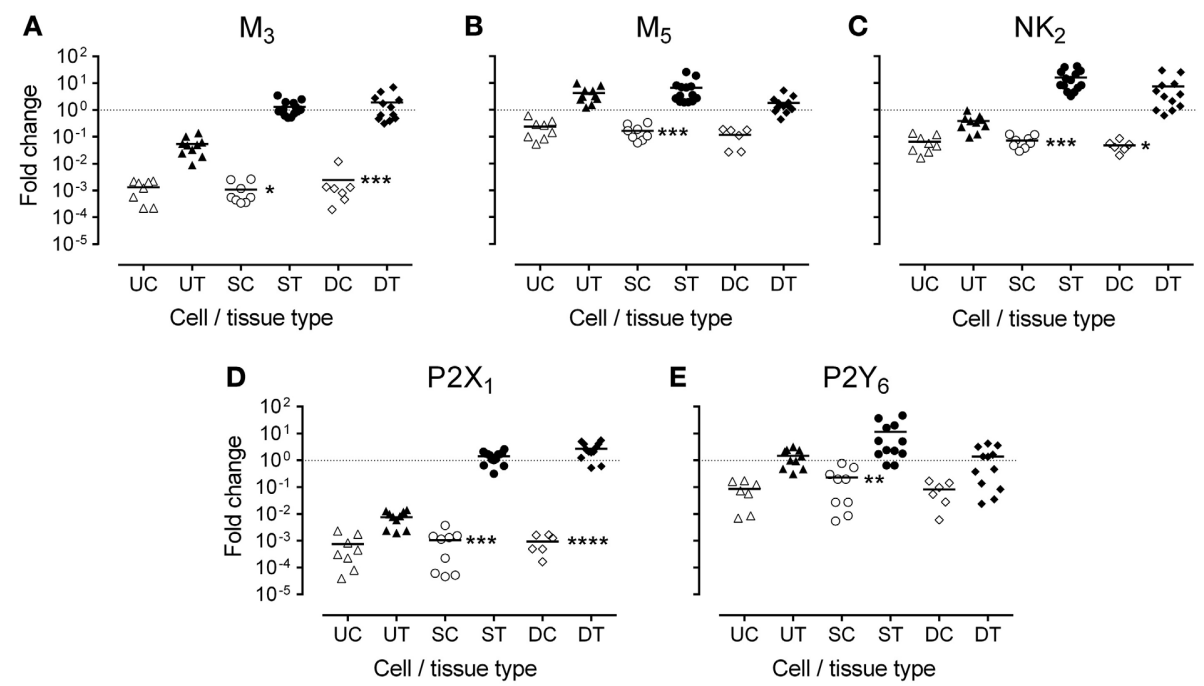

FIGURE 3 | Expression of mRNA for $(A)$ muscarinic $\left(M_{3}\right)$, (B) muscarinic $\left(\mathrm{M}_{5}\right),(\mathrm{C})$ tachykinin $\left(\mathrm{NK}_{2}\right),(\mathrm{D})$ purinergic $\left(\mathrm{P} \mathrm{X}_{1}\right)$, and $(\mathrm{E})$ purinergic $\left(\mathrm{P} \mathrm{Y}_{6}\right)$ receptors, in urothelium, suburothelium, and detrusor tissue (UT, ST, DT) and cultured cells (UC, SC, DC) in porcine bladder $(\boldsymbol{n}=\mathbf{6 - 1 4})$. Data are expressed as fold change relative to GAPDH and the calibrator. The bar represents the mean, and the dotted line is drawn at 1. Significant reductions in gene expression in cell culture compared with corresponding native tissue were observed. ${ }^{*} P<0.05$; ${ }^{*} P<0.01$; ${ }^{* * *} P<0.001 ;{ }^{* * * *} P<0.0001$ (One-Way ANOVA followed by Bonferroni's multiple comparisons test). 


\section{FUNCTIONAL STUDIES}

Cultured suburothelial and detrusor cells did not respond to $\mathrm{ACh}$ and the cholinergic agonist carbachol, nor to NKA, and the $\mathrm{P}_{2} \mathrm{X}_{1}$ selective agonist $\beta, \gamma$-MeATP, at any concentration (up to $0.1 \mathrm{mM}$ for NKA, $1 \mathrm{mM}$ for ACh, and $\beta, \gamma$-MeATP, or $10 \mathrm{mM}$ for carbachol) or time point up to $5 \mathrm{~min}$ (data not shown). In contrast, when $\mathrm{KCl}(80 \mathrm{mM})$ was applied to cultured smooth muscle cell, $60-70 \%$ cells showed visible responses to $\mathrm{KCl}$. The detachment of a few cells from the well surface at this concentration was also observed (data not shown). The higher concentrations of $\mathrm{KCl}(160 \mathrm{mM})$ resulted in detachments of more cells. These results suggested that cultured cells can contract in response to $\mathrm{KCl}$. Moreover, suburothelial and detrusor strips contracted in a concentration-dependent manner to ACh, NKA, and $\beta, \gamma$-MeATP, and $\mathrm{KCl}$ (data not shown), verifying the efficacy of the drug solutions.

\section{DISCUSSION}

Here, we have successfully cultured three different cell types from porcine bladders [as described in Cheng et al. (2011)] with an aim to study gene expression of some key receptors in bladder contraction and afferent signaling. We hypothesized that each cell type may express different genes according to their function in the bladder. This study showed that the expression of muscarinic $\mathrm{M}_{3}$, tachykinin $\mathrm{NK}_{2}$, and purinergic $\mathrm{P} 2 \mathrm{X}_{1}$ receptors was high in fresh detrusor and suburothelium, and lower in fresh urothelial cells. Their corresponding receptor proteins have been demonstrated to have contractile functions in the urinary bladder (Mussap et al., 1996; Vial and Evans, 2000; Fetscher et al., 2002; Yoshimura et al., 2008). However, our major finding was that expression of these three genes was significantly decreased in primary culture. We were not able to detect the $\mathrm{NK}_{1}$ transcript in the porcine bladder, despite using primers derived from sequences conserved across a broad range of mammalian species, which showed a positive $\mathrm{NK}_{1}$ product in human colon. This is unexpected given the prominent role of the $\mathrm{NK}_{1}$ receptor in micturition in other mammalian bladders (Yoshimura et al., 2008). Overall, our original hypothesis, that urothelial cells, smooth muscle cells and myofibroblasts (suburothelial cells) should be characterized by a different set of genetic markers, was not substantiated. It is worth noting that the detrusor and suburothelium would contain various cell types (e.g., nerves, blood vessels, etc) in addition to smooth muscle and myofibroblasts, respectively. Thus, the transcripts might have been originally associated with a variety of cell types that did not grow in culture. Furthermore, the expression level of a transcript may not be related to the expression level of its associated protein.

The function of muscarinic $M_{5}$ receptors in bladder is unclear due to the continuing lack of a selective receptor antagonist, but they are known to be associated with the urothelium (Mansfield et al., 2005). Here, we found that these receptors were associated with all three cell populations, which was consistent with our previous finding in the human bladder, where $\mathrm{M}_{5}$ receptor transcript was expressed in both detrusor and mucosa (Mansfield et al., 2005). Unlike $M_{3}$ receptor, the loss $M_{5}$ expression in cell culture was rather moderate.

Muscarinic receptors respond to the parasympathetic neurotransmitter acetylcholine, to contract the detrusor, resulting in bladder emptying. The main receptor involved in the bladder detrusor muscle contraction is the $\mathrm{M}_{3}$ receptor (Choppin et al., 1998; Sellers et al., 2000; Chess-Williams et al., 2001), the major target for the treatment of lower urinary tract symptoms such as urinary frequency and urgency. Likewise, tachykinin peptides including NKA are able to contract the detrusor predominately via $\mathrm{NK}_{2}$ receptors (Bushfield et al., 1995; Sadananda et al., 2008), and also have sensory functions in bladder (Maggi et al., 1988, 1991). ACh and NKA can also contract the suburothelium (Sadananda et al., 2008). It is assumed that these agonists cause detrusor contraction directly via smooth muscle cells, but the mechanisms underlying suburothelial contraction are less clear. It has previously been hypothesized that suburothelial myofibroblasts may be the cell types causing contraction of the porcine bladder mucosa (Sadananda et al., 2008, 2009), but histological staining of mucosal and suburothelial strips reveals variable amounts of thin smooth muscle bands, of different appearance to detrusor muscle bundles. As expected, both suburothelial and detrusor tissue strips contracted to the muscarinic and tachykinin agonists, suggesting the presence of $\mathrm{M}_{3}$ (Sellers et al., 2000) and $\mathrm{NK}_{2}$ (Sadananda et al., 2008) receptors in the native tissue. However, the cultured cells of both suburothelium and smooth muscle were completely unable to contract to either ACh or NKA, correlating with the loss of receptor expression in cell culture. However, it should be noted that downregulated expression of receptor transcripts in cultured conditions is not necessarily reflected by the lack of contractile response of the cells to the receptor agonists. Other mechanisms may be involved. For instance, cell responses in the culture may be affected by the way of cell attachment to the plastic well surface. Individual cells in the culture lack of synergistic activities as a consequence of the loss of cellto-cell communication. Furthermore, the expression contractile elements may also be downregulated, or contractile protein phosphorylation is reduced during culture. Further studies to elucidate the mechanisms should be of interest; however, they are beyond the scope of this report. It should be noted that muscarinic receptors can mediate smooth muscle proliferation in cell culture and may contribute to bladder remodeling (Arrighi et al., 2013).

As seen for ACh and NKA, the cultured suburothelial and smooth muscle cells failed to contract to the selective $\mathrm{P}_{2} \mathrm{X}_{1}$ agonist $\beta, \gamma$-MeATP, in accordance with the loss of $\mathrm{P}_{2} \mathrm{X}_{1}$ receptors in culture. The endogenous purinergic agonist ATP exerts a broad range of functions in bladder by binding to $\mathrm{P} 2 \mathrm{X}$ and $\mathrm{P} 2 \mathrm{Y}$ receptors (Burnstock, 2007, 2013). ATP has neural functions and is a parasympathetic co-transmitter contributing to bladder emptying via $\mathrm{P}_{2} \mathrm{X}_{1}$ mediated detrusor contraction (Chancellor et al., 1992; Akino et al., 2008). The most abundant P2X receptor in the mammalian bladder, $\mathrm{P}_{2} \mathrm{X}_{1}$ (Longhurst et al., 1996), is widely accepted to have excitatory effects on detrusor smooth muscle. Non-neuronal ATP can be released from urothelial and other cell types, and we have previously demonstrated that ATP release is significantly higher in urothelial and myofibroblast (suburothelial) cultures than in detrusor culture (Cheng et al., 2011). Similarly, more ATP is released from suburothelial than detrusor strips (Sadananda et al., 2009; Yoshida et al., 2009). ATP released from bladder lining can stimulate $\mathrm{P}_{2} \mathrm{X}_{3}$ receptors on the nerves (Burnstock, 2007), which activates afferent signaling and thus, 
elicit the sensation of bladder fullness to the brain. Therefore, the role of ATP in bladder mucosa is more associated with the sensation of bladder filling rather than emptying.

Our studies showed that $\mathrm{P}_{2} \mathrm{Y}_{6}$ was expressed in all bladder layers, particularly in suburothelial tissue, supporting the previous observation that $\mathrm{P}_{2} \mathrm{Y}_{6}$ is a predominant purinoceptor in bladder suburothelium, particularly on myofibroblasts (Sui et al., 2006). The role of $\mathrm{P}_{2} \mathrm{Y}_{6}$ in bladder is not clear, but may be involved in bladder relaxation (Tong et al., 1997). Note that activation of $\mathrm{P}_{2} \mathrm{Y}_{6}$ receptors by UDP enhanced ATP-mediated contractile force in mouse whole bladder, suggesting synergism between $\mathrm{P}_{2} \mathrm{X}_{1}$ and $\mathrm{P}_{2} \mathrm{Y}_{6}$ receptors (Yu et al., 2013). Further studies to uncover the underlying purinergic mechanisms are warranted.

The unresponsiveness of cultured suburothelial and detrusor muscle cells to the muscarinic, tachykinin, and purinergic agonists demonstrated altered functionality in cell culture. The phenotypic alteration of smooth muscle cells in culture has previously been reported (Nair et al., 2011; Huber and Badylak, 2012). The former group suggested that proliferation reduces the expression of specific genes and proteins involved in contraction of smooth muscle cells, an effect observed by day 4 in cell culture (Nair et al., 2011). Thus, even in primary culture, cells do not appear to express those receptor proteins which are not required for their function in the culture. Additionally our data showed that the gene expression in all cell types reached the same pattern in the culture. This may indicate that different cell types, which were differentiated in the native tissue, may undergo myogenic conversion after 2 weeks in the culture. Several studies have reported the conversion of fibroblasts, myofibroblasts and muscle cells depending on the experimental conditions (Darby et al., 1990; Salvatori et al., 1995; Chiavegato et al., 1999; Darby and Hewitson, 2007).

In conclusion, this study showed that the expression of the receptor transcripts involved in muscle contraction $\left(\mathrm{M}_{3}, \mathrm{NK}_{2}\right.$, and $\mathrm{P}_{2} \mathrm{X}_{1}$ ) decreased in the primary cultured cells (SC and DC). The unresponsiveness of cultured cells to muscarinic, tachykinin, and purinergic receptor agonists correlates with the low expression of receptor transcripts. This suggests the reduction in expression of not only the transcripts, but also of their related proteins. These results provide evidence that cultured cells do not necessarily mimic the actions exerted by intact tissues.

\section{AUTHOR CONTRIBUTIONS}

Forough Bahadory conducted the experiments, analyzed the data, and wrote the manuscript. Kate $\mathrm{H}$. Moore provided intellectual input. Lu Liu provided intellectual input, technical and analytical support and contributed to the manuscript. Elizabeth Burcher provided intellectual input and wrote the manuscript.

\section{ACKNOWLEDGMENTS}

We thank Mr. Ray Weir and the staff of the Picton Abattoir for generous supply of pig bladders, and Tim Cowan for tissue delivery. We would also like to thank Dr. Ying Cheng for advising on the cell culture, Irit Markus for assistance with the molecular work and Dr. Fei Shang for assistance in immunohistochemistry.
This study was supported by the National Health and Medical Research Council of Australia \#527502.

\section{SUPPLEMENTARY MATERIAL}

The Supplementary Material for this article can be found online at: http://www.frontiersin.org/journal/10.3389/fphar. 2013.00148/abstract

\section{REFERENCES}

Akino, H., Chapple, C. R., McKay, N., Cross, R. L., Murakami, S., Yokoyama, O., et al. (2008). Spontaneous contractions of the pig urinary bladder: the effect of ATP-sensitive potassium channels and the role of the mucosa. BJU Int. 102, 1168-1174. doi: 10.1111/j.1464-410X.2008.07782.x

Arrighi, N., Bodei, S., Zani, D., Michel, M. C., Simeone, C., Cosciani Cunico, S., et al. (2013). Different muscarinic receptor subtypes modulate proliferation of primary human detrusor smooth muscle cells via Akt/PI3K and map kinases. Pharmacol. Res. 74, 1-6. doi: 10.1016/j.phrs.2013. 04.007

Birder, L. A. (2013). Nervous network for lower urinary tract function. Int. J. Urol. 20, 4-12. doi: 10.1111/j.1442-2042.2012.03210.x

Burnstock, G. (2007). Purine and pyrimidine receptors. Cell Mol. Life Sci. 64, 1471-1483. doi: 10.1007/s00018-007-6497-0

Burnstock, G. (2013). Purinergic signaling in the lower urinary tract. Acta Physiol. 207, 40-52. doi: 10.1111/apha.12012

Bushfield, M., Metcalfe, M., and Naylor, A. M. (1995). Activation of the micturition reflex by NK2 receptor stimulation in the anaesthetized guinea-pig. Br. J. Pharmacol. 115, 875-882. doi: 10.1111/j.1476-5381.1995.tb15891.x

Chancellor, M. B., Kaplan, S. A., and Blaivas, J. G. (1992). The cholinergic and purinergic components of detrusor contractility in a whole rabbit bladder model. J. Urol. 148, 906-909.

Cheng, Y., Mansfield, K., Sandow, S., Sadananda, P., Burcher, E., and Moore, K. H. (2011). Porcine bladder urothelial, myofibroblast, and detrusor muscle cells: characterization and ATP release. Front. Pharmacol. 2:27. doi: 10.3389/fphar.2011.00027

Chess-Williams, R., Chapple, C. R., Yamanishi, T., Yasuda, K., and Sellers, D. J. (2001). The minor population of M3-receptors mediate contraction of human detrusor muscle in vitro. J. Auton. Pharmacol. 21, 243-248. doi: 10.1046/j.13652680.2001.00231.x

Chiavegato, A., Roelofs, M., Franch, R., Castellucci, E., Sarinella, F., and Sartore, S. (1999). Differential expression of SM22 isoforms in myofibroblasts and smooth muscle cells from rabbit bladder. J. Muscle Res. Cell Motil. 20, 133-146. doi: 10.1023/A:1005411201187

Choppin, A., Eglen, R. M., and Hegde, S. S. (1998). Pharmacological characterization of muscarinic receptors in rabbit isolated iris sphincter muscle and urinary bladder smooth muscle. Br. J. Pharmacol. 124, 883-888. doi: 10.1038/sj.bjp.0701920

Dai, L., Perera, D. S., King, D. W., Southwell, B. R., Burcher, E., and Liu, L. (2012). Hemokinin-1 stimulates prostaglandin $\mathrm{E}_{2}$ production in human colon through activation of cyclooxygenase-2 and inhibition of 15 hydroxyprostaglandin dehydrogenase. J. Pharmacol. Exp. Ther. 340, 27-36. doi: 10.1124/jpet.111.186155

Darby, I., Skalli, O., and Gabbiani, G. (1990). Alpha-smooth muscle actin is transiently expressed by myofibroblasts during experimental wound healing. Lab. Invest. 63, 21-29.

Darby, I. A., and Hewitson, T. D. (2007). Fibroblast differentiation in wound healing and fibrosis. Int. Rev. Cytol. 257, 143-179. doi: 10.1016/S00747696(07)57004-X

Fetscher, C., Fleichman, M., Schmidt, M., Krege, S., and Michel, M. C. (2002). M3 muscarinic receptors mediate contraction of human urinary bladder. Br. J. Pharmacol. 136, 641-643. doi: 10.1038/sj.bjp. 0704781

Fry, C. H., Sui, G. P., Kanai, A. J., and Wu, C. (2007). The function of suburothelial myofibroblasts in the bladder. Neurourol. Urodyn. 26, 914-919. doi: 10.1002/nau.20483

Huber, A., and Badylak, S. F. (2012). Phenotypic changes in cultured smooth muscle cells: limitation or opportunity for tissue engineering of hollow organs. J. Tissue Eng. Regen. Med. 6, 505-511. doi: 10.1002/term.451 
Ishizuka, O., Mattiasson, A., and Andersson, K. E. (1995). Tachykinin effects on bladder activity in conscious normal rats. J. Urol. 154, 257-261. doi: 10.1016/ S0022-5347(01)67290-2

Kumar, V., Chapple, C. C., and Chess-Williams, R. (2004). Characteristics of adenosine triphosphate release from porcine and human normal bladder. J. Urol. 172, 744-747. doi: 10.1097/01.ju.0000131244.67160.f4ABSTRACT

Liu, L., Markus, I., Saghire, H. E., Perera, D. S., King, D. W., and Burcher, E. (2011). Distinct differences in tachykinin gene expression in ulcerative colitis, Crohn's disease, and diverticular disease: a role for hemokinin-1. Neurogastroent. Motil. 23, 475-483. doi: 10.1111/j.1365-2982.2011.01685.x

Longhurst, P. A., Schwegel, T., Folander, K., and Swanson, R. (1996). The human $\mathrm{P} 2 \mathrm{X} 1$ receptor: molecular cloning, tissue distribution, and localization to chromosome 17. Biochim. Biophys. Acta 1308, 185-188. doi: 10.1016/01674781(96)00112-1

Maggi, C. A., Geppetti, P., Santicioli, P., Frilli, S., Giuliani, S., Furio, M., et al. (1988). Tachykinin-like immunoreactivity in the mammalian urinary bladder: correlation with the functions of the capsaicin-sensitive sensory nerves. Neuroscience. 26, 233-242. doi: 10.1016/0306-4522(88)90140-6

Maggi, C. A., Patacchini, R., Santicioli, P., and Giuliani, S. (1991). Tachykinin antagonists and capsaicin-induced contraction of the rat isolated urinary bladder: evidence for tachykinin-mediated cotransmission. Br. J. Pharmacol. 103, 1535-1541. doi: 10.1111/j.1476-5381.1991.tb09823.x

Mansfield, K. J., Liu, L., Mitchelson, F. J., Moore, K. H., Millard, R. J., and Burcher, E. (2005). Muscarinic receptor subtypes in human bladder detrusor and mucosa, studied by radioligand binding and quantitative competitive RT-PCR: changes in ageing. Br. J. Pharmacol. 144, 1089-1099. doi: 10.1038/sj.bjp.0706147

McCloskey, K. D. (2010). Interstitial cells in the urinary bladder-localization and function. Neurourol. Urodyn. 29, 82-87. doi: 10.1002/nau.20739

Mussap, C. J., Stamatakos, C., and Burcher, E. (1996). Radioligand binding, autoradiographic and functional studies demonstrate tachykinin NK-2 receptors in dog urinary bladder. J. Pharmacol. Exp. Ther. 279, 423-434.

Nair, D. G., Han, T. Y., Lourenssen, S., and Blennerhassett, M. G. (2011). Proliferation modulates intestinal smooth muscle phenotype in vitro and in colitis in vivo. Am. J. Physiol. Gastrointest Liver Physiol. 300, 903-913. doi: 10.1152/ ajpgi.00528.2010

Ochodnicky, P., Uvelius, B., Andersson, K. E., and Michel, M. C. (2013). Autonomic nervous control of the urinary bladder. Acta Physiol. 207, 16-33. doi: 10.1111/apha.12010

Otomo, R., Shimoda, N., Satoh, S., Sato, K., Ogawa, O., and Kato, T. (1999). The role of ATP-receptor in controlling the urinary bladder and urethral function in rats. Nihon Hinyokika Gakkai Zasshi. 90, 681-687.

Pfaffl, M. W. (2001). A new mathematical model for relative quantification in realtime RT-PCR. Nucleic Acids Res. 29, 45-49. doi: 10.1093/nar/29.9.e45

Sadananda, P., Chess-Williams, R., and Burcher, E. (2008). Contractile properties of the pig bladder mucosa in response to neurokinin A: a role for myofibroblasts. Br. J. Pharmacol. 153, 1465-1473. doi: 10.1038/bjp.2008.29

Sadananda, P., Kao, F. C., Liu, L., Mansfield, K. J., and Burcher, E. (2012). Acid and stretch, but not capsaicin, are effective stimuli for ATP release in the porcine bladder mucosa: are ASIC and TRPV1 receptors involved. Eur. J. Pharmacol. 683, 252-259. doi: 10.1016/j.ejphar.2012.02.041

Sadananda, P., Shang, F., Liu, L., Mansfield, K. J., and Burcher, E. (2009). Release of ATP from rat urinary bladder mucosa: role of acid, vanilloids, and stretch. Br. J. Pharmacol. 158, 1655-1662. doi: 10.1111/j.1476-5381.2009.00431.x

Salvatori, G., Lattanzi, L., Coletta, M., Aguanno, S., Vivarelli, E., Kelly, R., et al. (1995). Myogenic conversion of mammalian fibroblasts induced by differentiating muscle cells. J. Cell Sci. 108, 2733-2739.

Sellers, D. J., Yamanishi, T., Chapple, C. R., Couldwell, C., Yasuda, K., and ChessWilliams, R. (2000). M3 muscarinic receptors but not M2 mediate contraction of the porcine detrusor muscle in vitro. J. Auton. Pharmacol. 20, 171-176. doi: 10.1046/j.1365-2680.2000.00181.x
Sui, G. P., Wu, C., and Fry, C. H. (2006). Characterization of the purinergic receptor subtype on guinea-pig suburothelial myofibroblasts. BJU Int. 97, 1327-1331. doi: 10.1111/j.1464-410X. 2006.06200.x

Templeman, L., Sellers, D. J., Chapple, C. R., Rosario, D. J., Hay, D. P., and Chess-Williams, R. (2003). Investigation of neurokinin-2 and -3 receptors in the human and pig bladder. BJU Int. 92, 787-792. doi: 10.1046/j.1464410X.2003.04458.x

Tong, Y. C., Hung, Y. C., and Cheng, J. T. (1997). Evidence of P2Y-purinoceptor mediated bladder neck smooth muscle post-contractile relaxation in the male mini-pig. Neurosci. Lett. 225, 181-184. doi: 10.1016/S0304-3940(97) 00212-7

Vial, C., and Evans, R. J. (2000). P2X receptor expression in mouse urinary bladder and the requirement of $\mathrm{P}_{2} \mathrm{X}_{1}$ receptors for functional $\mathrm{P} 2 \mathrm{X}$ receptor responses in the mouse urinary bladder smooth muscle. Br. J. Pharmacol. 131, 1489-1495. doi: 10.1038/sj.bjp. 0703720

Whitbeck, C., Chichester, P., Sokol, R., and Levin, R. M. (2007). Role of nitric oxide in urinary bladder function: effect of L-arginine. Urol. Int. 78, 30-36. doi: $10.1159 / 000096931$

Wiseman, O. J., Fowler, C. J., and Landon, D. N. (2003). The role of the human bladder lamina propria myofibroblast. BJU Int. 91, 89-93. doi: 10.1046/j.1464410X.2003.03802.x

Wu, C., Sui, G. P., and Fry, C. H. (2004). Purinergic regulation of guinea pig suburothelial myofibroblasts. J. Physiol. 559, 231-243. doi: 10.1113/jphysiol.2004.067934

Yoshida, M., Masunaga, K., Nagata, T., Maeda, Y., Miyamoto, Y., Kudoh, J., et al. (2009). Attenuation of non-neuronal adenosine triphosphate release from human bladder mucosa by antimuscarinic agents. LUTS. 1, 88-92. doi: 10.1111/j.1757-5672. 2009.00049.x

Yoshimura, N., Kaiho, Y., Miyazato, M., Yunoki, T., Tai, C., Chancellor, M. B., et al. (2008). Therapeutic receptor targets for lower urinary tract dysfunction. Naunyn Schmiedebergs Arch. Pharmacol. 377, 437-448. doi: 10.1007/s00210007-0209-Z

Yu, W., Sun, X., Robson, S. C., and Hill, W. G. (2013). Extracellular UDP enhances $\mathrm{P} 2 \mathrm{X}$-mediated bladder smooth muscle contractility via $\mathrm{P}_{2} \mathrm{Y}_{6}$ activation of the phospholipase C/inositol trisphosphate pathway. FASEB J. 27, 1895-1903. doi: 10.1096/fj.12-219006

Conflict of Interest Statement: The authors declare that the research was conducted in the absence of any commercial or financial relationships that could be construed as a potential conflict of interest.

Received: 11 August 2013; paper pending published: 22 August 2013; accepted: 10 November 2013; published online: 28 November 2013.

Citation: Bahadory F, Moore KH, Liu L and Burcher E (2013) Gene expression of muscarinic, tachykinin, and purinergic receptors in porcine bladder: comparison with cultured cells. Front. Pharmacol. 4:148. doi: 10.3389/fphar.2013.00148

This article was submitted to Cardiovascular and Smooth Muscle Pharmacology, a section of the journal Frontiers in Pharmacology.

Copyright (C) 2013 Bahadory, Moore, Liu and Burcher. This is an open-access article distributed under the terms of the Creative Commons Attribution License (CC BY). The use, distribution or reproduction in other forums is permitted, provided the original author(s) or licensor are credited and that the original publication in this journal is cited, in accordance with accepted academic practice. No use, distribution or reproduction is permitted which does not comply with these terms. 